\title{
Effects of collagen membranes enriched with in vitro-differentiated N1E-115 cells on rat sciatic nerve regeneration after end-to-end repair
}

\author{
Sandra Amado ${ }^{3 \dagger}$, Jorge M Rodrigues ${ }^{1,2+}$, Ana L Luís ${ }^{1,2+}$, Paulo AS Armada-da-Silva ${ }^{3}$, Márcia Vieira ${ }^{1}$, Andrea Gartner ${ }^{1}$, \\ Maria J Simões', António P Veloso ${ }^{3}$, Michele Fornaro ${ }^{4}$, Stefania Raimondo ${ }^{4}$, Artur SP Varejão ${ }^{5}$, Stefano Geuna ${ }^{4^{*}}$, \\ Ana C Maurício ${ }^{1,2^{*}}$
}

\begin{abstract}
Peripheral nerves possess the capacity of self-regeneration after traumatic injury but the extent of regeneration is often poor and may benefit from exogenous factors that enhance growth. The use of cellular systems is a rational approach for delivering neurotrophic factors at the nerve lesion site, and in the present study we investigated the effects of enwrapping the site of end-to-end rat sciatic nerve repair with an equine type III collagen membrane enriched or not with N1E-115 pre-differentiated neural cells. After neurotmesis, the sciatic nerve was repaired by end-to-end suture (End-to-End group), end-to-end suture enwrapped with an equine collagen type III membrane (End-to-EndMemb group); and end-to-end suture enwrapped with an equine collagen type III membrane previously covered with neural cells pre-differentiated in vitro from N1E-115 cells (End-to-EndMembCell group). Along the postoperative, motor and sensory functional recovery was evaluated using extensor postural thrust (EPT), withdrawal reflex latency (WRL) and ankle kinematics. After 20 weeks animals were sacrificed and the repaired sciatic nerves were processed for histological and stereological analysis. Results showed that enwrapment of the rapair site with a collagen membrane, with or without neural cell enrichment, did not lead to any significant improvement in most of functional and stereological predictors of nerve regeneration that we have assessed, with the exception of EPT which recovered significantly better after neural cell enriched membrane employment. It can thus be concluded that this particular type of nerve tissue engineering approach has very limited effects on nerve regeneration after sciatic end-to-end nerve reconstruction in the rat.
\end{abstract}

\section{Background}

Nerve regeneration is a complex biological phenomenon. In the peripheral nervous system, nerves can spontaneously regenerate without any treatment if nerve continuity is maintained (axonotmesis) whereas more severe type of injuries must be surgically treated by direct end-to-end surgical reconnection of the damaged nerve ends [1-3]. Unfortunately, the functional outcomes of nerve repair are in many cases unsatisfactory [4] thus calling for research in order to reveal more effective strategies for improving nerve regeneration. However,

\footnotetext{
* Correspondence: stefano.geuna@unito.it; ana.colette@hotmail.com + Contributed equally

'Centro de Estudos de Ciência Animal (CECA), Instituto de Ciências e Tecnologias Agrárias e Agro-Alimentares (ICETA), Universidade do Porto (UP), Portugal

${ }^{4}$ Department of Clinical and Biological Sciences, University of Turin, Italy
}

recent advances in neuroscience, cell culture, genetic techniques, and biomaterials provide optimism for new treatments for nerve injuries [5-17].

The use of materials of natural origin has several advantages in tissue engineering. Natural materials are more likely to be biocompatible than artificial materials. Also, they are less toxic and provide a good support to cell adhesion and migration due to the presence of a variety of surface molecules. Drawbacks of natural materials include potential difficulties in their isolation and controlled scale-up [11]. In addition to the use of intact natural tissues, a great deal of research has focused on the use of purified natural extracellular matrix (ECM) molecules, which can be modified to serve as appropriate scaffolding [11]. ECM molecules, such as laminin, fibronectin and collagen have also been shown to play a 
significant role in axonal development and regeneration $[12,18-27]$. For example, silicone tubes filled with laminin, fibronectin, and collagen led to a better regeneration over a $10 \mathrm{~mm}$ rat sciatic nerve gap compared to empty silicone controls [9]. Collagen filaments have also been used to guide regenerating axons across $20-30 \mathrm{~mm}$ defects in rats [23-27]. Further studies have shown that oriented fibers of collagen within gels, aligned using magnetic fields, provide an improved template for neurite extension compared to randomly oriented collagen fibers $[28,29]$. Finally, rates of regeneration comparable to those using a nerve autograft have been achieved using collagen tubes containing a porous collagen-glycosaminoglycan matrix [30-32]. Nerve regeneration requires a complex interplay between cells, ECM, and growth factors. The local presence of growth factors plays an important role in controlling survival, migration, proliferation, and differentiation of the various cell types involved in nerve regeneration [12-14,33]. Therefore, therapies with relevant growth factors received increasing attention in recent years although growth factor therapy is a difficult task because of the high biological activity (in pico- to nanomolar range), pleiotrophic effects (acting on a variety of targets), and short biological half-life (few minutes to hours) [34]. Thus, growth factors should be administered locally to achieve an adequate therapeutic effect with little adverse reactions and the short biological half-life of growth factors demands for a delivery system that slowly releases locally the molecules over a prolonged period of time. Employment of biodegradable membranes enriched with a cellular system producing neurotrophic factors has been suggested to be a rational approach for improving nerve regeneration after neurotmesis [11].

The aim of this study was thus to verify if rat sciatic nerve regeneration after end-to-end reconstruction can be improved by seeding in vitro differentiated N1E-115 neural cells on a type III equine collagen membrane and enwrap the membrane around the lesion site. The N1E115 cell line has been established from a mouse neuroblastoma [35] and have already been used with conflicting results as a cellular system to locally produce and deliver neurotrophic factors [12-14,36,37]. In vitro, the N1E-115 cells undergo neuronal differentiation in response to dimethylsulfoxide (DMSO), adenosine 3', 5'-cyclic monophosphate (cAMP), or serum withdrawal [38-43,36,37,12-14]. Upon induction of differentiation, proliferation of N1E-115 cells ceases, extensive neurite outgrowth is observed and the membranes become highly excitable [38-43,36,37,12-14]. The interval period of 48 hours of differentiation was previously determined by measurement of the intracellular calcium concentration $\left(\left[\mathrm{Ca}^{2+}\right] \mathrm{i}\right)$. At this time point, the N1E-115 cells present already the morphological characteristics of neuronal cells but cell death due to increased $\left[\mathrm{Ca}^{2+}\right] \mathrm{i}$ is not yet occurring as described elsewhere [38-43,36,37,12-14].

\section{Methods \\ Cell culture}

The N1E-115 cells, clones of cells derived from the mouse neuroblastoma C-130035 retain numerous biochemical, physiological, and morphological properties of neuronal cells in culture [38-43,36,37,12-14]. N1E-115 neuronal cells were cultured in Petri dishes (around $2 \times$ $10^{6}$ cells) over collagen type III membranes (Gentafleece ${ }^{\ominus}$, Resorba Wundversorgung $\mathrm{GmbH}+$ Co. KG, Baxter AG) at $37^{\circ} \mathrm{C}, 5 \% \mathrm{CO}_{2}$ in a humidified atmosphere with 90\% Dulbecco's Modified Eagle's Medium (DMEM; Gibco) supplemented with $10 \%$ fetal bovine serum (FBS, Gibco), $100 \mathrm{U} / \mathrm{ml}$ penicillin, and $100 \mu \mathrm{g} / \mathrm{ml}$ streptomycin (Gibco). The culture medium was changed every 48 hours and the Petri dishes were observed daily. The cells were passed or were supplied with differentiating medium containing $1.5 \%$ of DMSO once they reached approximately $80 \%$ confluence, mostly 48 hours after plating (and before the rats' surgery). The differentiating medium was composed of 96\% DMEM supplemented with $2.5 \%$ of FBS, $100 \mathrm{U} / \mathrm{ml}$ penicillin, $100 \mu \mathrm{g} / \mathrm{ml}$ streptomycin and $1.5 \%$ of DMSO [12-14,36,37].

\section{Surgical procedure}

Adult male Sasco Sprague Dawley rats (Charles River Laboratories, Barcelona, Spain) weighing 300-350 g, were randomly divided in 3 groups of 6 or 7 animals each. All animals were housed in a temperature and humidity controlled room with 12-12 hours light/dark cycles, two animals per cage (Makrolon type 4, Tecniplast, VA, Italy), and were allowed normal cage activities under standard laboratory conditions. The animals were fed with standard chow and water ad libitum. Adequate measures were taken to minimize pain and discomfort taking in account human endpoints for animal suffering and distress. Animals were housed for two weeks before entering the experiment. For surgery, rats were placed prone under sterile conditions and the skin from the clipped lateral right thigh scrubbed in a routine fashion with antiseptic solution. The surgeries were performed under an M-650 operating microscope (Leica Microsystems, Wetzlar, Germany). Under deep anaesthesia (ketamine $90 \mathrm{mg} / \mathrm{Kg}$; xylazine $12.5 \mathrm{mg} / \mathrm{Kg}$, atropine $0.25 \mathrm{mg} /$ $\mathrm{Kg}$ i.m.), the right sciatic nerve was exposed through a skin incision extending from the greater trochanter to the mid-thigh distally followed by a muscle splitting incision. After nerve mobilisation, a transection injury was performed (neurotmesis) immediately above the terminal nerve ramification using straight microsurgical scissors. Rats were then randomly assigned to three experimental groups. In one group (End-to-End), 
immediate cooptation with 7/0 monofilament nylon epineurial sutures of the 2 transected nerve endings was performed, in a second group (End-to-EndMemb) nerve transection was reconstructed by end-to-end suture, like in the first group, and then enveloped by a membrane of equine collagen type III. In a third group (End-toEndMembCell) animals received the same treatment as the previous group but with equine collagen type III membranes covered with neural cells differentiated in vitro. Sciatic nerves from the contralateral site were left intact in all groups and served as controls. To prevent autotomy, a deterrent substance was applied to rats' right foot $[44,45]$. The animals were intensively examined for signs of autotomy and contracture during the postoperative and none presented severe wounds, infections or contractures. All procedures were performed with the approval of the Veterinary Authorities of Portugal in accordance with the European Communities Council Directive of November 1986 (86/609/EEC).

\section{Evaluation of motor performance (EPT) and nociceptive function (WRL)}

Motor performance and nociceptive function were evaluated by measuring extensor postural thrust (EPT) and withdrawal reflex latency (WRL), respectively. The animals were tested pre-operatively (week-0), at weeks 1, 2, and every two weeks thereafter until week-20. The animals were gently handled, and tested in a quiet environment to minimize stress levels. The EPT was originally proposed by Thalhammer and collaborators, in 1995 [46] as a part of the neurological recovery evaluation in the rat after sciatic nerve injury. For this test, the entire body of the rat, excepting the hind-limbs, was wrapped in a surgical towel. Supporting the animal by the thorax and lowering the affected hind-limb towards the platform of a digital balance, elicits the EPT. As the animal is lowered to the platform, it extends the hind-limb, anticipating the contact made by the distal metatarsus and digits. The force in grams (g) applied to the digital platform balance (model TM 560; Gibertini, Milan, Italy) was recorded. The same procedure was applied to the contralateral, unaffected limb. Each EPT test was repeated 3 times and the average result was considered. The normal (unaffected limb) EPT (NEPT) and experimental EPT (EEPT) values were incorporated into an equation (Equation 1) to derive the functional deficit (varying between 0 and 1), as described by Koka and Hadlock, in 2001 [47].

$$
\text { Motor Deficit }=(\text { NEPT }- \text { EEPT }) / \text { NEPT }
$$

To assess the nociceptive withdrawal reflex (WRL), the hotplate test was modified as described by Masters and collaborators [48]. The rat was wrapped in a surgical towel above its waist and then positioned to stand with the affected hind paw on a hot plate at $56^{\circ} \mathrm{C}$ (model 35-D, IITC Life Science Instruments, Woodland Hill, CA). WRL is defined as the time elapsed from the onset of hotplate contact to withdrawal of the hind paw and measured with a stopwatch. Normal rats withdraw their paws from the hotplate within $4.3 \mathrm{~s}$ or less [49]. The affected limbs were tested 3 times, with an interval of $2 \mathrm{~min}$ between consecutive tests to prevent sensitization, and the three latencies were averaged to obtain a final result [50,51]. If there was no paw withdrawal after $12 \mathrm{~s}$, the heat stimulus was removed to prevent tissue damage, and the animal was assigned the maximal WRL of $12 \mathrm{~s}$ [52].

\section{Kinematic Analysis}

Ankle kinematics during the stance phase of the rat walk was recorded prior nerve injury (week-0), at week2 and every 4 weeks during the 20-week follow-up time. Animals walked on a Perspex track with length, width and height of respectively 120,12 , and $15 \mathrm{~cm}$. In order to ensure locomotion in a straight direction, the width of the apparatus was adjusted to the size of the rats during the experiments, and a darkened cage was placed at the end of the corridor to attract the animals. The rats gait was video recorded at a rate of 100 images per second (JVC GR-DVL9800, New Jersey, USA). The camera was positioned perpendicular to the mid-point of the corridor length at a 1-m distance thus obtaining a visualization field of 14-cm wide. Only walking trials with stance phases lasting between 150 and $400 \mathrm{~ms}$ were considered for analysis, since this corresponds to the normal walking velocity of the rat $(20-60 \mathrm{~cm} / \mathrm{s})$ [52-54]. The video images were stored in a computer hard disk for latter analysis using an appropriate software APAS $^{\oplus}$ (Ariel Performance Analysis System, Ariel Dynamics, San Diego, USA). 2-D biomechanical analysis (sagittal plan) was carried out applying a two-segment model of the ankle joint, adopted from the model firstly developed by Varejão and collaborators [52-55]. Skin landmarks were tattooed at points in the proximal edge of the tibia, in the lateral malleolus and, in the fifth metatarsal head. The rats' ankle angle was determined using the scalar product between a vector representing the foot and a vector representing the lower leg. With this model, positive and negative values of position of the ankle joint indicate dorsiflexion and plantarflexion, respectively. For each stance phase the following time points were identified: initial contact (IC), opposite toeoff (OT), heel-rise (HR) and toe-off (TO) [52-55], and were time normalized for $100 \%$ of the stance phase. The normalized temporal parameters were averaged over all recorded trials. Angular velocity of the ankle joint was also determined where negative values 
correspond to dorsiflexion. Four steps were analysed for each animal [55].

\section{Histological and Stereological analysis}

A 10-mm-long segment of the sciatic nerve distal to the site of lesion was removed, fixed, and prepared for quantitative morphometry of myelinated nerve fibers. A $10-\mathrm{mm}$ segment of uninjured sciatic nerve was also withdrawn from control animals $(\mathrm{N}=6)$. The harvested nerve segments were immersed immediately in a fixation solution containing $2.5 \%$ purified glutaraldehyde and $0.5 \%$ saccarose in $0.1 \mathrm{M}$ Sorensen phosphate buffer for 6-8 hours. Specimens were processed for resin embedding as described in details elsewhere [56,57]. Series of $2-\mu \mathrm{m}$ thick semi-thin transverse sections were cut using a Leica Ultracut UCT ultramicrotome (Leica Microsystems, Wetzlar, Germany) and stained by Toluidine blue for stereological analysis of regenerated nerve fibers. The slides were observed with a DM4000B microscope equipped with a DFC320 digital camera and an IM50 image manager system (Leica Microsystems, Wetzlar, Germany). One semi-thin section from each nerve was randomly selected and used for the morphoquantitative analysis. The total cross-sectional area of the nerve was measured and sampling fields were then randomly selected using a protocol previously described [57-59]. Bias arising from the "edge effect" was coped with the employment of a two-dimensional disector procedure which is based on sampling the "tops" of fibers $[60,61]$. Mean fiber density in each disector was then calculated by dividing the number of nerve fibers counted by the disector's area $\left(\mathrm{N} / \mathrm{mm}^{2}\right)$. Finally, total fiber number $(\mathrm{N})$ in the nerve was estimated by multiplying the mean fiber density by the total cross-sectional area of the whole nerve. Two-dimensional disector probes were also used for the unbiased selection of a representative sample of myelinated nerve fibers for estimating circle-fitting diameter and myelin thickness. Precision and accuracy of the estimates were evaluated by calculating the coefficient of variation $(\mathrm{CV}=\mathrm{SD} /$ mean $)$ and coefficient of error (CE $=\mathrm{SEM} /$ mean) [57-59].

\section{Statistical analysis}

Two-way mixed factorial ANOVA was used to test for the effect of time in the End-to-End group (within subjects effect; 12 time points) and experimental groups (between subjects effect, 3 groups). The sphericity assumption was evaluated by the Mauchly's test and when this test could not be computed or when sphericity assumption was violated, adjustment of the degrees of freedom was done with the Greenhouse-Geiser's epsilon. When time main effect was significant (within subjects factor), simple planned contrasts (General Linear Model, simple contrasts) were used to compare pooled data across the three experimental groups along the recovery with data at week-0. When a significant main effect of treatment existed (between subjects factor), pairwise comparisions were carried out using the Tukey's HSD test. At week-0, kinematic data was recorded only from the End-to-End group so the main effect of time was evaluated only in this group. Evaluation of the main effect of treatment on ankle motion variables used only data after nerve injury. In this case, and when appropriate, pairwise comparisons were made using the Tukey's HSD test. Statistical comparisons of stereological morpho-quantitative data on nerve fibers were accomplished with one-way ANOVA test. Statistical significance was established as $\mathrm{p}<0.05$. All statistical procedures were performed by using the statistical package SPSS (version 14.0, SPSS, Inc) except stereological data that were analysed using the software "Statistica per discipline bio-mediche" (McGraw-Hill, Milan, Italy). All data in this study is presented as mean \pm standard error of the mean (SEM).

\section{Results}

\section{Motor deficit and Nociception function} Motor deficit (EPT)

Before sciatic injury, EPT was similar in both hindlimbs in all experimental groups (figure 1). In the first week after sciatic nerve transection, near total EPT loss was observed in the operated hindlimb, leading to a motor deficit ranging between 83 to $90 \%$. The EPT response steadily improved during recovery but at week-20 the EPT values of the injured side were still significantly lower compared to values at week-0 ( $\mathrm{p}<0.05)$. A significant main effect for treatment was found $\left[\mathrm{F}_{(2,17)}=\right.$ 14.202; $\mathrm{p}=0.000$ ], with pairwise comparisons showing significantly better recovery of the EPT response in the End-to-EndMembCell group when compared to the other two experimental groups ( $\mathrm{p}<0.05)$. At week-20, motor deficit decreased to $27 \%$ in the End-to-EndMembCell and to $34 \%$ and $42 \%$ in the End-to-End and End-toEndMemb groups, respectively (figure 1).

\section{Nociception function (WRL)}

In the week after sciatic transaction, all the animals presented a severe loss of sensory and nociception function acutely after sciatic nerve transection and the WRL test has to be interrupted at the 12 s-cutoff time (figure 2). During the following weeks there was recovery in paw nociception which was more clearly seen between weeks 6 and 8 post-surgery. At week- 6 , half of the animals still had no withdrawal response to the noxious thermal stimulus in the operated side, which is in contrast with week-8, when all animals presented a consistent, although delayed, response. Despite such improvement in WRL response, contrast analysis showed persistence of sensory deficit in all groups by the end of the 20- 


\section{EPT}

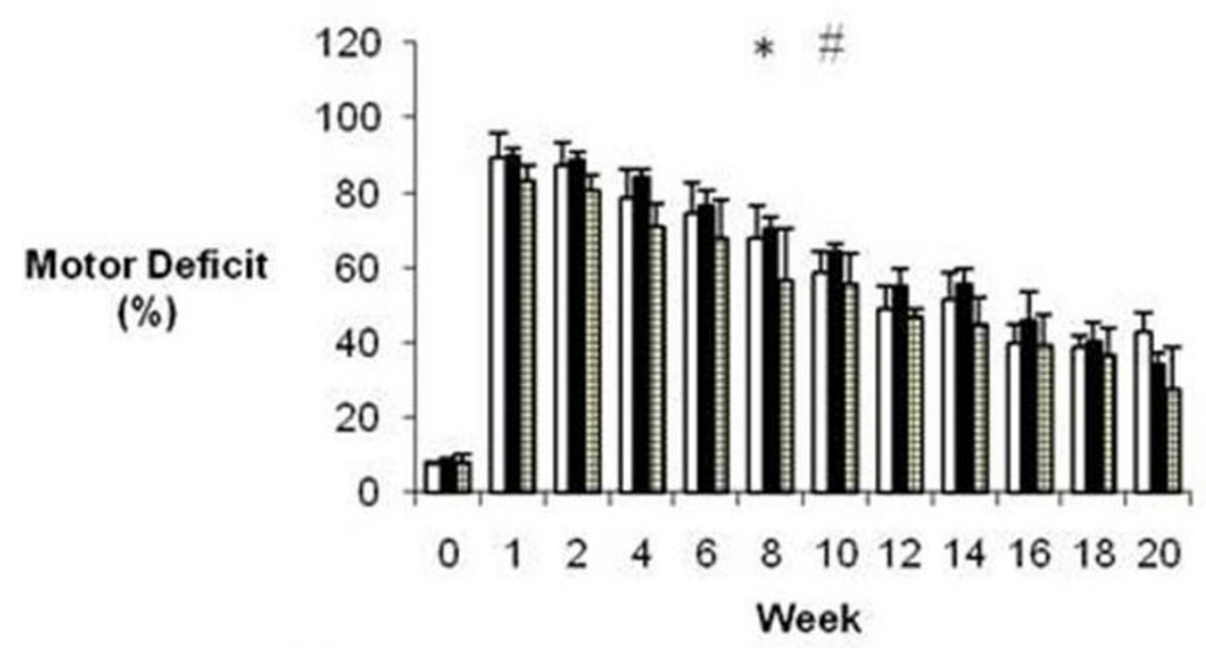

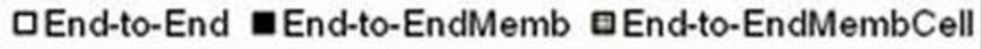

Figure 1 Weekly values of the percentage of motor deficit obtained by the Extensor Postural Thrust (EPT) test. * Significantly different from week-0 all groups pooled together $(p<0.05)$. \# Group End-to-EndMembCell significantly different from the other groups $(p<0.05)$. Results are presented as mean and standard error of the mean (SEM).

weeks recovery time $(\mathrm{p}<0.05)$. No differences between the groups was observed in the level of WRL impairment after the sciatic nerve transection $\left[\mathrm{F}_{(2,17)}=1.563\right.$; $\mathrm{p}=0.238]$.

\section{Kinematics Analysis}

Figures 3 and 4 display the mean plots, respectively for ankle joint angle and ankle joint velocity during the stance phase of the rat walk. Comparisons to the normal ankle motion can only be draw for the End-to-End group for reasons explained in the Methods section. In the weeks following sciatic nerve transection, ankle joint motion became severely abnormal, particularly throughout the second half of stance corresponding to the push-off sub-phase. In clear contrast to the normal pattern of ankle movement, at week-2 post-injury animals were unable to extend this joint and dorsiflexion continued increasing during the entire stance, which is explained by the paralysis of plantarflexor muscles. The pattern of the ankle joint motion seemed to have improved only slightly during recovery. Contrast analysis was performed for each of the kinematic parameters (tables 1 and 2) with somewhat different results. For OT velocity and $H R$ angle no differences existed before and after sciatic nerve transection, whereas for OT angle differences from pre-injury values were significant only at weeks 2 and 16 of recovery ( $<0.05)$. The angle at IC showed a unique pattern of changes, being unaffected at week-2 post-injury and altered from normal in the following weeks of recovery. Probably the most consistent results are those of HR velocity, TO angle and TO velocity. These parameters were affected immediately after the nerve injury and remained abnormal along the entire 20 -weeks recovery period $(\mathrm{p}<0.05)$. The effect of the different tissue engineering strategies was assessed comparing the kinematic data of the experimental groups only during the recovery period (see Methods). Statistical analysis demonstrated that the collagen membrane and the cells had no or little effect on ankle motion pattern recovery. Generally, no differences in the kinematic parameters were found between the groups. Exceptions were IC velocity in the End-to-End$M e m b C e l l$ group, which was different from the other two groups ( $\mathrm{p}<0.05)$, and OT angle in the End-to-End$M e m b$ group that was also different from the other two groups $(\mathrm{p}<0.05)$.

\section{Histological and Stereological Analysis}

Figure 5 shows representative light micrographs of the regenerated sciatic nerves of the three groups (figure 5A-C) and control sciatic normal nerves (figure 5D). As expected, regeneration of axons was organized in many smaller fascicles in comparison to controls. The results of the stereological analysis of myelinated nerve fibers are reported in Table 3. Statistical analysis by ANOVA test revealed no significant $(\mathrm{p}>0.05)$ difference 


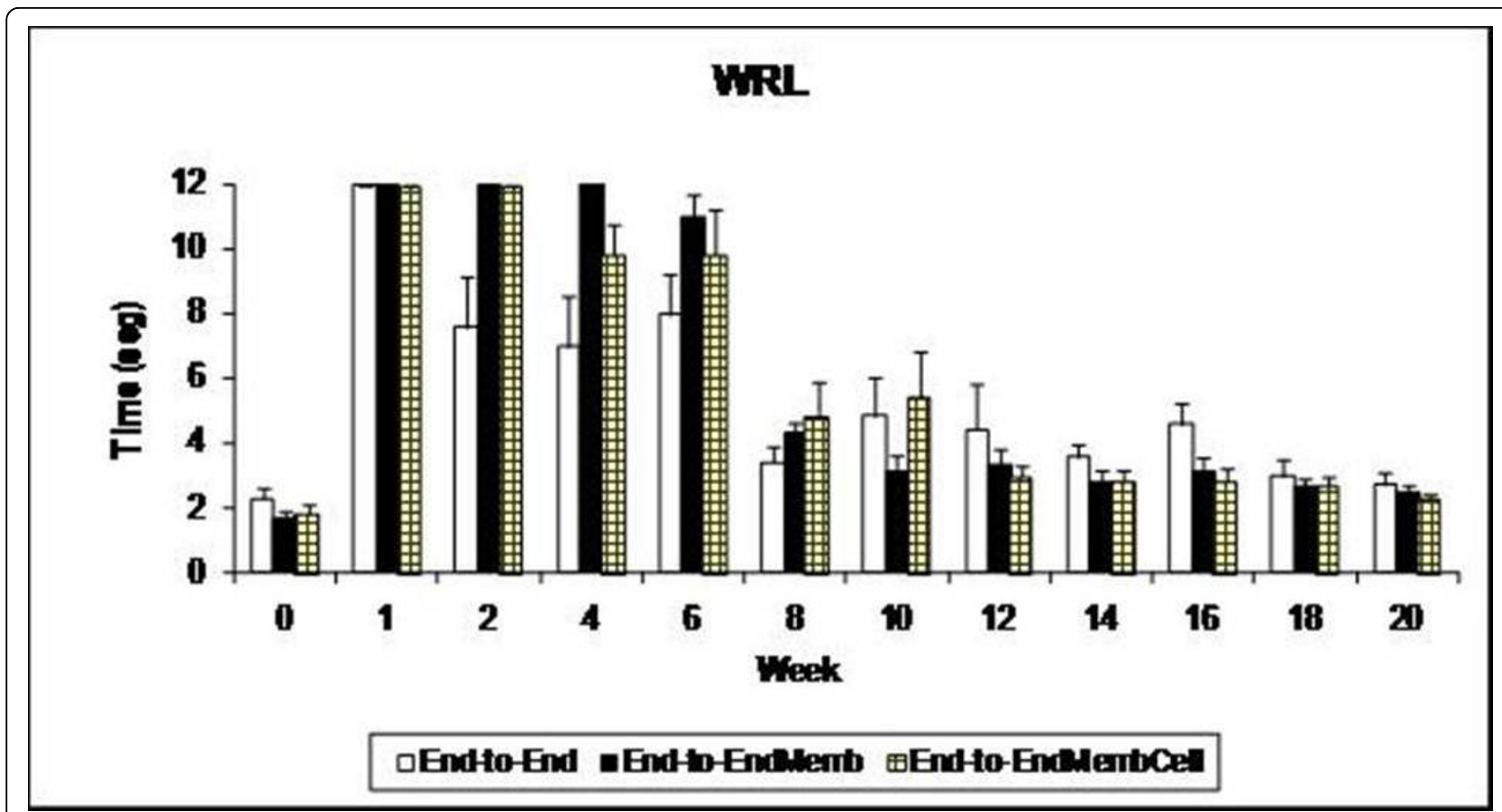

Figure 2 Weekly values of the withdrawal reflex latency test. At week-1 all animals failed in responding to the noxious thermal stimulus within the $12 \mathrm{sec}$ cut-off time. No differences between the percentages of motor deficit obtained by the Extensor Postural Thrust (EPT) test. * Significantly different from week-0 all groups pooled together $(p<0.05)$. Results are presented as mean and standard error of the mean (SEM).

regarding any of the morphological parameters investigated in the regenerated axons from the three experimental groups. On the other hand, comparison between regenerated and control nerves showed, as expected, the presence of a significantly $(\mathrm{p}<0.05)$ higher density and total number of myelinated axons in experimental groups accompanied by a significantly $(\mathrm{p}<0.05)$ lower fiber diameter.

\section{Discussion}

Transected peripheral nerves can regenerate provided that a connection is available between the proximal and distal severed stumps and, when no substance loss occurred, surgical treatment consists in direct end-toend suturing of the nerve ends $[1-3,62,63]$. However, in spite of the progress of microsurgical nerve repair, the outcome of nerve reconstruction is still far from being optimal $^{4}$. Since during regeneration axons require neurotrophic support, they could benefit from the presence of a growth factors delivery cell system capable of responding to stimuli of the local environment during axonal regeneration.

In the present study, we aimed at investigating the effects of enwrapping the site of end-to-end rat sciatic nerve repair with equine type III collagen nerve membranes either alone or enriched with N1E-115 pre-differentiated into neural cells in the presence of $1.5 \%$ of
DMSO. The rationale for the utilization of the N1E-115 cells was to take advantages of the properties of these cells as a neural-like cellular source of neurotrophic factors [12-14,36,37].

Results showed that enwrapment with a collagen membrane, with or without neural cell enrichment, did not lead to any significant improvement in most of functional and stereological predictors of nerve regeneration that we have assessed. The only exception was represented by motor deficit recovery which was significantly improved after lesion site enwrapment with membrane enriched with neural cells pre-differentiated from N1E-115 cell line.

Natural tissues possess several advantages when compared to synthetic materials, when use to reconstruct peripheral nerves after injury. Natural materials are more likely to be biocompatible than artificial materials, are less toxic, and provide a support structure to promote cell adhesion and migration. Drawbacks, on the other hand, include potential difficulties with isolation and controlled scale-up. In addition to intact acellular tissues, a great deal of research has focused on the use of purified natural ECM proteins and glycosaminoglycans, which can be modified to serve as appropriate scaffolding. ECM molecules, such as laminin, collagen, and fibronectin, have been shown to play a significant role in axonal development and repair in the body 

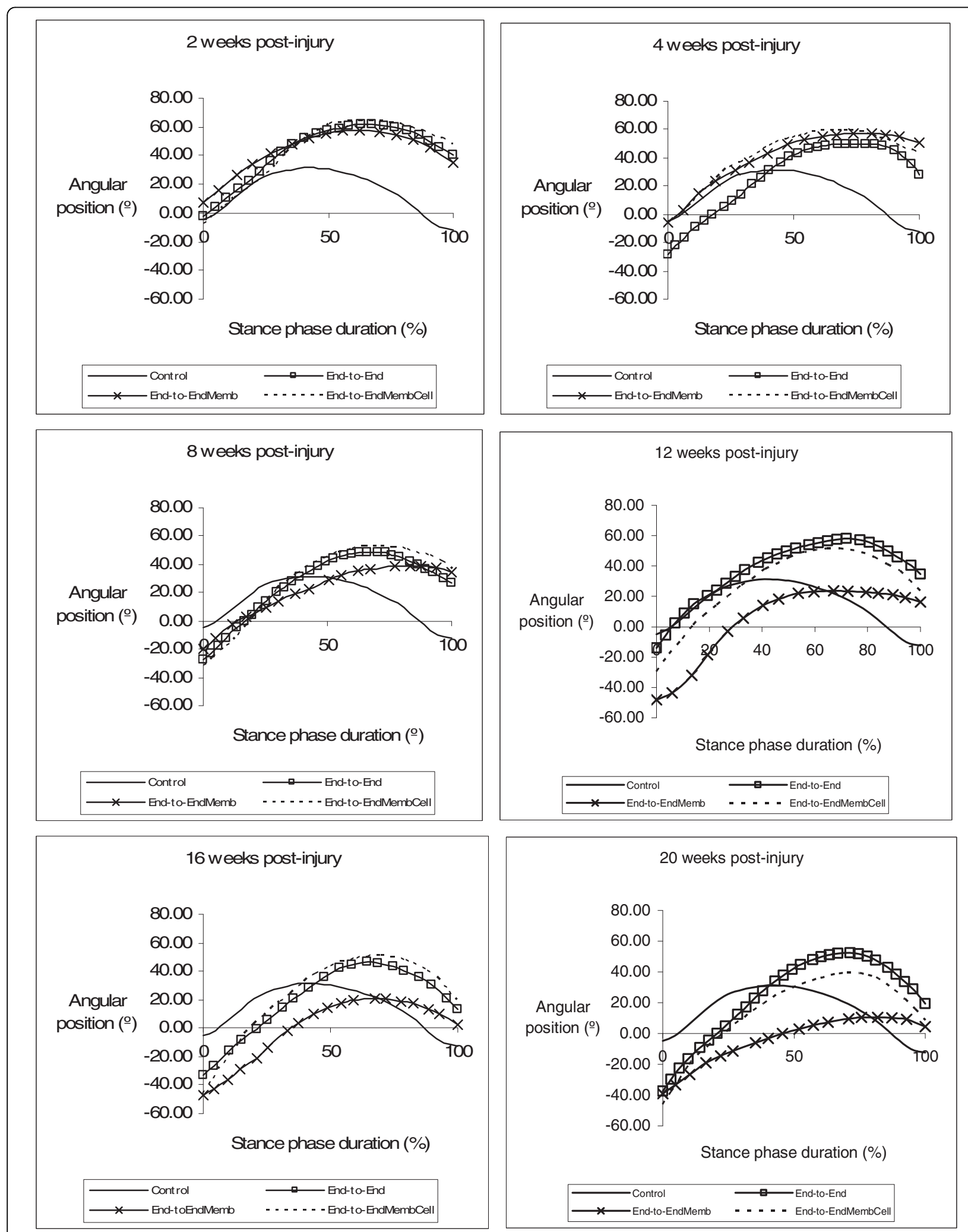

Figure 3 Kinematics plots in the sagittal plane for the angular position $\left(^{\circ}\right)$ of the ankle as it moves through the stance phase, during the healing period of $\mathbf{2 0}$ weeks. The mean of each group is plotted. 

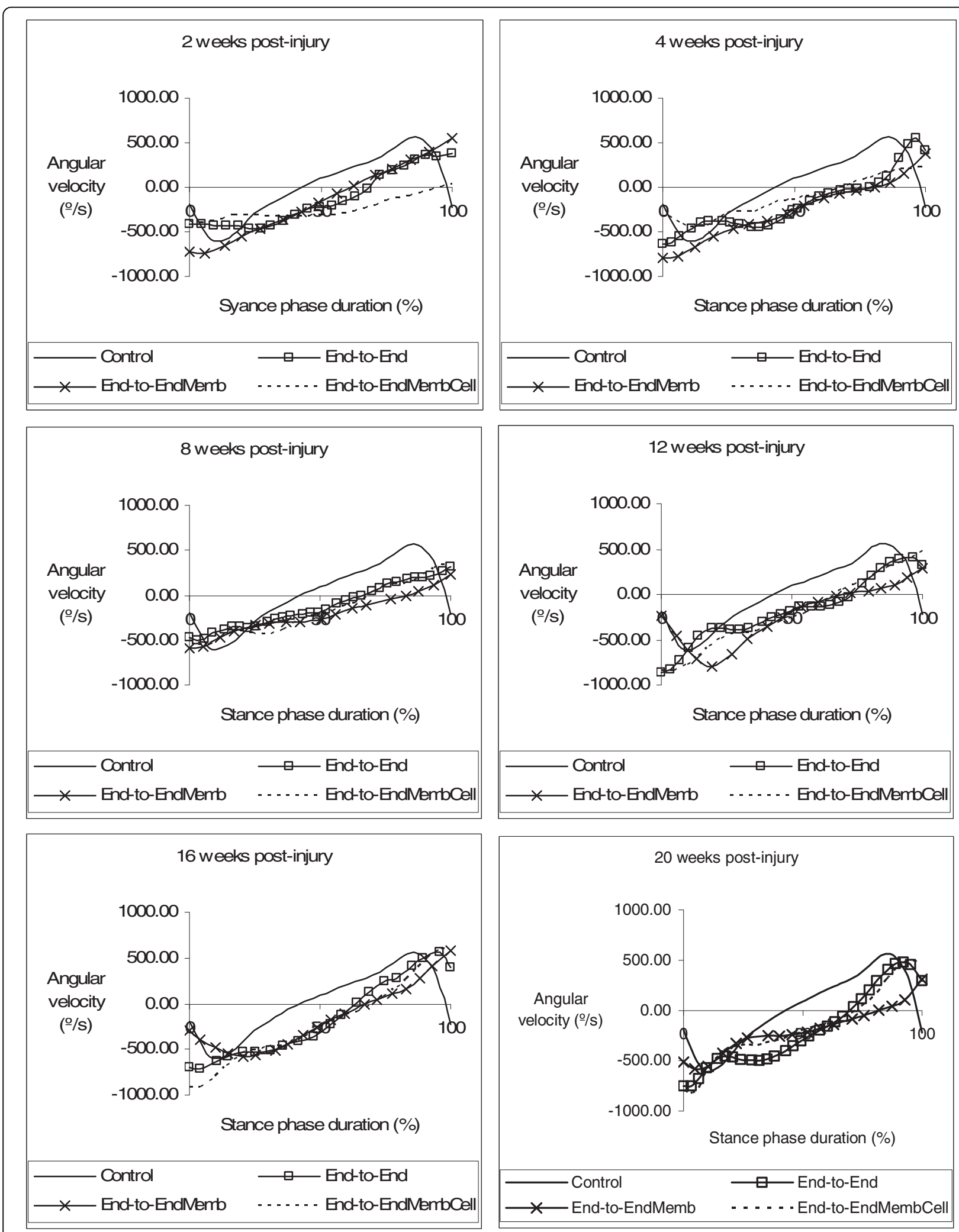

Figure 4 Kinematics plots in the sagittal plane for the angular velocity $(\%)$ of the ankle as it moves through the stance phase, during the healing period of 20 weeks. The mean of each group is plotted. 
Table 1 Ankle kinematics and stance duration analysis were carried out prior to nerve injury (week-0), at week-2, and every 4 weeks during the 20 -week follow-up period.

\begin{tabular}{|c|c|c|c|c|c|c|c|c|}
\hline $\begin{array}{l}\text { Temporal } \\
\text { Parameter }\end{array}$ & & Week 0 & Week 2 & Week 4 & Week 8 & Week 12 & Week 16 & Week 20 \\
\hline \multirow[t]{3}{*}{ IC } & End-to-End & $-4.84 \pm 3.00$ & $2.70 \pm 1.29$ & $-30.11 \pm 5.38$ & $-20.88 \pm 4.22$ & $-28.36 \pm 3.84$ & $-38.92 \pm 4.82$ & $-52.83 \pm 6.46$ \\
\hline & End-to-EndMemb & & $7.19 \pm 2.94$ & $-6.25 \pm-2.55$ & $\begin{array}{l}-19.65 \pm \\
-8.02\end{array}$ & $\begin{array}{l}-48.15 \pm \\
-19.66\end{array}$ & $\begin{array}{l}-46.87 \pm \\
-19.13\end{array}$ & $\begin{array}{l}-39.03 \pm \\
-15.93\end{array}$ \\
\hline & $\begin{array}{l}\text { End-to- } \\
\text { EndMembCell }\end{array}$ & & $4.95 \pm 0.68$ & $\begin{array}{l}-31.59 \pm \\
12.98\end{array}$ & $-23.79 \pm 2.47$ & $-29.57 \pm 5.74$ & $-42.25 \pm 11.38$ & $-46.04 \pm 9.29$ \\
\hline \multirow[t]{3}{*}{ OT } & End-to-End & $25.65 \pm 1.08$ & $\begin{array}{l}36.74 \pm \\
4.71\end{array}$ & $18.75 \pm 2.81$ & $25.58 \pm 8.88$ & $24.79 \pm 2.62$ & $4.71 \pm 4.35$ & $16.61 \pm 3.96$ \\
\hline & End-to-EndMemb & & $\begin{array}{l}20.37 \pm \\
4.61\end{array}$ & $21.54 \pm 9.92$ & $9.78 \pm 18.75$ & $4.26 \pm 18.44$ & $-19.51 \pm 16.74$ & $-18.70 \pm 20.74$ \\
\hline & $\begin{array}{l}\text { End-to- } \\
\text { EndMembCell }\end{array}$ & & $\begin{array}{l}33.15 \pm \\
2.98\end{array}$ & $25.08 \pm 4.86$ & $28.15 \pm 8.57$ & $24.54 \pm 8.91$ & $21.75 \pm 5.76$ & $16.47 \pm 6.73$ \\
\hline \multirow[t]{3}{*}{$\mathrm{HR}$} & End-to-End & $30.67 \pm 2.44$ & $\begin{array}{l}51.20 \pm \\
4.50\end{array}$ & $40.03 \pm 2.21$ & $36.82 \pm 5.96$ & $34.01 \pm 5.87$ & $34.30 \pm 3.35$ & $40.37 \pm 4.75$ \\
\hline & End-to-EndMemb & & $\begin{array}{l}52.46 \pm \\
2.16\end{array}$ & $48.04 \pm 5.49$ & $\begin{array}{l}29.65 \pm \\
22.49\end{array}$ & $20.89 \pm 21.10$ & $11.57 \pm 20.18$ & $4.16 \pm 26.71$ \\
\hline & $\begin{array}{l}\text { End-to- } \\
\text { EndMembCell }\end{array}$ & & $\begin{array}{l}54.80 \pm \\
2.44\end{array}$ & $44.16 \pm 3.90$ & $46.41 \pm 6.68$ & $43.69 \pm 6.09$ & $41.53 \pm 6.66$ & $29.08 \pm 7.55$ \\
\hline \multirow[t]{3}{*}{ TO } & End-to-End & $\begin{array}{l}-12.27 \pm \\
7.01\end{array}$ & $\begin{array}{l}41.49 \pm \\
3.23\end{array}$ & $39.33 \pm 3.03$ & $27.28 \pm 1.38$ & $28.04 \pm 3.11$ & $15.02 \pm 3.78$ & $12.16 \pm 3.43$ \\
\hline & End-to-EndMemb & & $\begin{array}{l}35.56 \pm \\
1.69\end{array}$ & $50.77 \pm 4.41$ & $\begin{array}{l}34.64 \pm \\
21.86\end{array}$ & $16.36 \pm 20.87$ & $2.12 \pm 18.58$ & $4.60 \pm 25.45$ \\
\hline & $\begin{array}{l}\text { End-to- } \\
\text { EndMembCell }\end{array}$ & & $\begin{array}{l}48.10 \pm \\
1.60\end{array}$ & $44.76 \pm 4.17$ & $36.40 \pm 6.11$ & $23.37 \pm 4.02$ & $18.64 \pm 5.76$ & $8.71 \pm 4.20$ \\
\hline
\end{tabular}

Values of the ankle angular position $\left(^{\circ}\right)$ at initial contact (IC); opposite toe-off (OT); heel-rise (HR); toe-off (TO) of the stance phase. Results are presented as mean and standard error of the mean (SEM). $\mathrm{N}$ corresponds to the number of rats within the experimental group.

Table 2 Ankle kinematics and stance duration analysis were carried out prior to nerve injury (wek-0), at week-2, and every 4 weeks during the 20 -week follow-up period.

\begin{tabular}{|c|c|c|c|c|c|c|c|c|}
\hline $\begin{array}{l}\text { Temporal } \\
\text { Parameter }\end{array}$ & & Week 0 & Week 2 & Week 4 & Week 8 & Week 12 & Week 16 & Week 20 \\
\hline \multirow[t]{3}{*}{ IC } & End-to-End & $\begin{array}{l}-194.15 \pm \\
44.35\end{array}$ & $\begin{array}{l}-448.33 \pm \\
66.25\end{array}$ & $\begin{array}{l}-604.86 \pm \\
66.95\end{array}$ & $\begin{array}{l}-351.64 \pm \\
73.81\end{array}$ & $\begin{array}{l}-639.43 \pm \\
120.70\end{array}$ & $\begin{array}{l}-809.90 \pm \\
88.67\end{array}$ & $\begin{array}{l}-647.63 \pm \\
81.94\end{array}$ \\
\hline & End-to-EndMemb & & $\begin{array}{l}-728.48 \pm \\
-297.40\end{array}$ & $\begin{array}{l}-785.62 \pm \\
-320.73\end{array}$ & $\begin{array}{l}-593.43 \pm \\
-242.26\end{array}$ & $\begin{array}{l}-234.56 \pm \\
-95.76\end{array}$ & $\begin{array}{l}-302.06 \pm \\
-123.31\end{array}$ & $\begin{array}{l}-514.54 \pm \\
-210.06\end{array}$ \\
\hline & $\begin{array}{l}\text { End-to- } \\
\text { EndMembCell }\end{array}$ & & $\begin{array}{l}-557.10 \pm \\
224.85\end{array}$ & $\begin{array}{l}-505.97 \pm \\
108.58\end{array}$ & $\begin{array}{l}-845.50 \pm \\
160.47\end{array}$ & $\begin{array}{l}-933.63 \pm \\
57.41\end{array}$ & $\begin{array}{l}-914.05 \pm \\
80.10\end{array}$ & $\begin{array}{l}-903.24 \pm \\
74.55\end{array}$ \\
\hline \multirow[t]{3}{*}{ OT } & End-to-End & $\begin{array}{l}-270.35 \pm \\
19.65\end{array}$ & $\begin{array}{l}-273.97 \pm \\
47.92\end{array}$ & $\begin{array}{l}-385.24 \pm \\
37.99\end{array}$ & $\begin{array}{l}-399.28 \pm \\
34.85\end{array}$ & $\begin{array}{l}-530.42 \pm \\
68.29\end{array}$ & $\begin{array}{l}-460.90 \pm \\
66.08\end{array}$ & $\begin{array}{l}-414.22 \pm \\
35.18\end{array}$ \\
\hline & End-to-EndMemb & & $\begin{array}{l}-641.95 \pm \\
-262.08\end{array}$ & $\begin{array}{l}-528.60 \pm \\
-215.80\end{array}$ & $\begin{array}{l}-321.92 \pm \\
-131.42\end{array}$ & $\begin{array}{l}-449.49 \pm \\
-183.50\end{array}$ & $\begin{array}{l}-582.66 \pm \\
-237.87\end{array}$ & $\begin{array}{l}-411.32 \pm \\
-167.92\end{array}$ \\
\hline & $\begin{array}{l}\text { End-to- } \\
\text { EndMembCell }\end{array}$ & & $\begin{array}{l}-357.80 \pm \\
43.21\end{array}$ & $\begin{array}{l}-495.68 \pm \\
82.13\end{array}$ & $\begin{array}{l}-372.17 \pm \\
33.65\end{array}$ & $\begin{array}{l}-467.31 \pm \\
76.14\end{array}$ & $\begin{array}{l}-471.29 \pm \\
20.94\end{array}$ & $\begin{array}{l}-278.67 \pm \\
20.71\end{array}$ \\
\hline \multirow[t]{3}{*}{$\mathrm{HR}$} & End-to-End & $\begin{array}{l}53.25 \pm \\
40.58\end{array}$ & $\begin{array}{l}-177.64 \pm \\
41.45\end{array}$ & $\begin{array}{l}-246.61 \pm \\
11.49\end{array}$ & $\begin{array}{l}-333.55 \pm \\
16.41\end{array}$ & $\begin{array}{l}-280.20 \pm \\
24.32\end{array}$ & $\begin{array}{l}-322.47 \pm \\
18.46\end{array}$ & $\begin{array}{l}-322.86 \pm \\
23.80\end{array}$ \\
\hline & End-to-EndMemb & & $\begin{array}{l}-265.19 \pm \\
28.15\end{array}$ & $\begin{array}{l}-301.10 \pm \\
65.99\end{array}$ & $\begin{array}{l}-268.48 \pm \\
64.92\end{array}$ & $\begin{array}{l}-114.06 \pm \\
82.52\end{array}$ & $\begin{array}{l}-327.76 \pm \\
86.17\end{array}$ & $\begin{array}{l}-222.91 \pm \\
51.33\end{array}$ \\
\hline & $\begin{array}{l}\text { End-to- } \\
\text { EndMembCell }\end{array}$ & & $\begin{array}{l}-353.02 \pm \\
24.39\end{array}$ & $\begin{array}{l}-285.60 \pm \\
21.13\end{array}$ & $-190.41 \pm 9.69$ & $\begin{array}{l}-286.61 \pm \\
57.54\end{array}$ & $\begin{array}{l}-283.54 \pm \\
12.24\end{array}$ & $\begin{array}{l}-216.29 \pm \\
21.36\end{array}$ \\
\hline \multirow[t]{3}{*}{ TO } & End-to-End & $\begin{array}{l}-221.38 \pm \\
91.28\end{array}$ & $\begin{array}{l}322.87 \pm \\
109.64\end{array}$ & $\begin{array}{l}327.44 \pm \\
31.23\end{array}$ & $\begin{array}{l}399.79 \pm \\
82.70\end{array}$ & $\begin{array}{l}403.59 \pm \\
57.88\end{array}$ & $\begin{array}{l}444.05 \pm \\
78.95\end{array}$ & $\begin{array}{l}193.03 \pm \\
130.15\end{array}$ \\
\hline & End-to-EndMemb & & $\begin{array}{l}554.31 \pm \\
69.27\end{array}$ & $\begin{array}{l}384.52 \pm \\
66.65\end{array}$ & $\begin{array}{l}227.17 \pm \\
123.13\end{array}$ & $\begin{array}{l}281.98 \pm \\
79.91\end{array}$ & $\begin{array}{l}577.14 \pm \\
155.51\end{array}$ & $\begin{array}{l}311.14 \pm \\
197.88\end{array}$ \\
\hline & $\begin{array}{l}\text { End-to- } \\
\text { EndMembCell }\end{array}$ & & $\begin{array}{l}248.78 \pm \\
30.40\end{array}$ & $\begin{array}{l}420.52 \pm \\
28.58\end{array}$ & $\begin{array}{l}355.25 \pm \\
43.90\end{array}$ & $\begin{array}{l}466.17 \pm \\
43.54\end{array}$ & $\begin{array}{l}551.88 \pm \\
43.74\end{array}$ & $\begin{array}{l}460.01 \pm \\
51.01\end{array}$ \\
\hline
\end{tabular}

Values of the ankle angular velocity ( $\%$ sec) at initial contact (IC); opposite toe-off (OT); heel-rise (HR); toe-off (TO) of the stance phase. Results are presented as mean and standard error of the mean (SEM). $\mathrm{N}$ corresponds to the number of rats within the experimental group. 
Table 3 Stereological quantitative assessment density, total number, diameter and myelin thickness of regenerated sciatic nerve fibers at week-20 after neurotmesis.

\begin{tabular}{lccc}
\hline & $\begin{array}{c}\mathbf{N} / \mathbf{m m}^{\mathbf{2}} \\
\text { Density }\end{array}$ & $\begin{array}{c}\mathbf{N} \\
\text { Number }\end{array}$ & $\begin{array}{c}\mathbf{D} \\
\text { Fiber diameter } \\
(\boldsymbol{\mu m})\end{array}$ \\
\hline EndtoEnd & $20,612 \pm 1,607$ & $14,624 \pm 1,642$ & $4.06 \pm 0.30$ \\
EndtoEndMemb & $23,575 \pm 1,018$ & $15,101 \pm 1,172$ & $3.87 \pm 0.18$ \\
EndtoEndMembCell & $22,394 \pm 1,750$ & $14,467 \pm 1,524$ & $3.96 \pm 0.21$ \\
Control & $15,905 \pm 287$ & $7,666 \pm 190$ & $6.66 \pm 0.12$ \\
\hline
\end{tabular}

Values are presented as mean \pm SEM.

$[19,24]$. There are a number of examples in which the ECM proteins laminin, fibronectin, and collagen have been used for nerve repair applications [12,18-27]. For example, silicone tubes filled with laminin, fibronectin, and collagen show improved regeneration over a $10 \mathrm{~mm}$ rat sciatic nerve gap compared to empty silicone controls [9]. Collagen filaments have also been used to guide regenerating axons across $20-30 \mathrm{~mm}$ defects in rats $[23,26,27]$. Further studies have shown that oriented fibers of collagen within gels, aligned using magnetic fields, provide an improved template for neurite extension compared to randomly oriented collagen fibers $[28,29]$. Rates of regeneration after neurotmesis comparable to those using a nerve autograft have been achieved using collagen tubes containing a porous collagen-glycosaminoglycan matrix [31,32].

Results of this study contribute to the lively debate about the employment of cell transplantation for improving post-traumatic nerve regeneration [64,65]. Actually, a great enthusiasm among researchers and especially the public opinion has risen over the last years about cell-based therapies in Regenerative Medicine [66-68] and there seems to be widespread conviction that this type of therapy is not only effective but also very safe in comparison to other pharmacological or surgical therapeutic approaches. By contrast, recent studies showed that cell-based therapy might be ineffective for improving nerve regeneration [66-69], and results of the present study are in line with these observations. Recently, it has even been shown that N1E-115 cell transplantation can also have negative results by hindering the nerve regeneration process after tubulisation repair [12]. Of course, the choice of the cell type to be used for transplantation is very important for the therapeutic success and use of another cell type could have led to better results, especially when the cellular system of choice is derived from autologous or heterologous stem cells1 $[1,12,15-17,64,70]$. Moreover, the construction of more appropriate tube-guides with
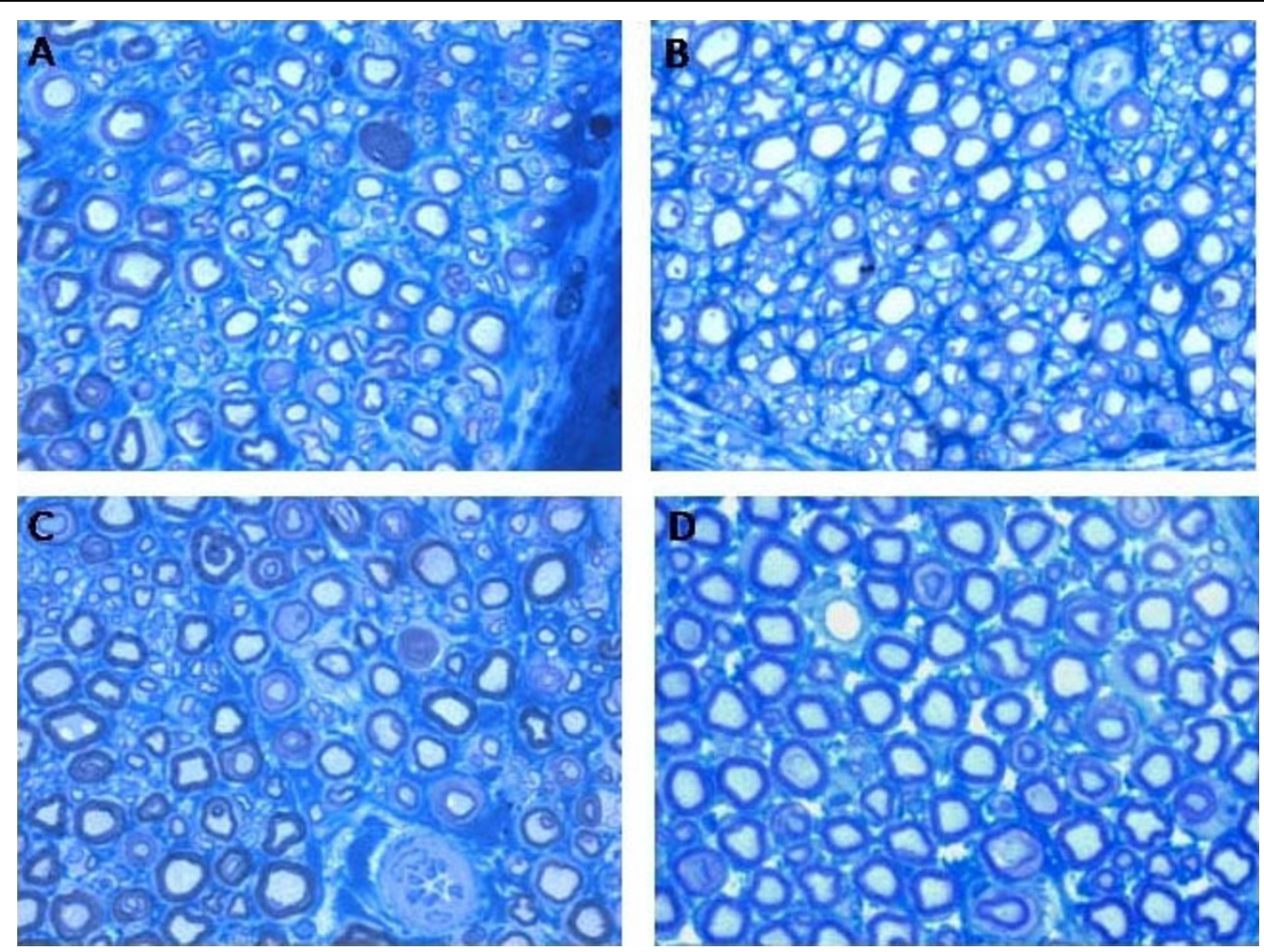

Figure 5 Representative high resolution photomicrographs of nerve fibers form regenerated $(A-C)$ and normal (D) rat sciatic nerves. $A$ : End-to-End. B:End-to-EndMemb. C:End-to-EndMembCell. Magnification $=\times 1,500$. 
integrated growth factor delivery systems and/or cellular components could improve the effectiveness of nerve tissue engineering. In fact, single-molded tube guides may not give sufficient control over both the mechanical properties and the delivery of bioactive agents. More complex devices will be needed, such as multilayered tube guides where growth factors are entrapped in polymer layers with varying physicochemical properties or tissue engineered tube guides containing viable stem cells $[1,12,15-17,64,70]$. The combination of two or more growth factors will likely exert a synergistic effect on nerve regeneration, especially when the growth factors belong to different families and act via different mechanisms. Combinations of growth factors can be expected to enhance further nerve regeneration, particularly when each of them is delivered at individually tailored kinetics [11,12,15-17,64,70,71]. The determination and control of suitable delivery kinetics for each of several growth factors will constitute a major hurdle both technically and biologically with the biological hurdle lying in the compliance with the naturally occurring cross talk between growth factors and cells. A solution to this problem may be the use of autologous stem cells because they can synthesize several growth factors and differentiate into Schwann cells which are critical for very long gaps [11,12,15-17,64,70,71].

Previous work already published by other research groups, point out a very interesting source of stem cells for nerve regeneration of peripheral nerve and spinal cord. They developed hair follicle pluripotent stem cells (hfPS) and have shown that these cells can differentiate to neurons, glial cells in vitro, and other cell types, and can promote nerve and spinal cord regeneration in vivo. These cells are located above the hair follicle bulge (hfPS cell area) and are nestin and CD34 positive, and keratin 15 negative [72-75]. The mouse hfPS cells were implanted into the gap region of the severed sciatic and tibial nerve of mice. These cells, after 6-8 weeks, transdifferentiated largely into Schwann cells. Also, blood vessels formed a network around the joined sciatic and tibial nerve. Function of the rejoined sciatic and tibial nerve was confirmed by contraction of the gastrocnemius muscle upon electrical stimulation and by walking track analysis [73-75]. hfPS cells can promote axonal growth and functional recovery after peripheral nerve injury, offering an important opportunity for future clinical application. These hfPS cells, in contrast to Embrionic stem cells, N1E-115 cells after in vitro differentiation and induced pluripotent stem cells, do not require any genetic manipulation, are readily accessible from any patient, and lack the ethical issues, do not form tumors.

\section{Acknowledgements}

The authors would like to gratefully acknowledge the valuable support by Dr. José Manuel Correia Costa, from Laboratório de Parasitologia, Instituto Nacional de Saúde Dr. Ricardo Jorge (INSRJ), Porto, Portugal. This work was supported by and by Fundação para a Ciência e Tecnologia (FCT) from Ministério da Ciência e Ensino Superior (MCES), Portugal, through the financed research project PTDC/CVT/64220/2006, and by the Regione Piemonte (Progetto Ricerca Sanitaria Finalizzata). Stefania Raimondo is recipient of a PostDoc grant partially supported by the Regione Piemonte (Azione Contenimento del Brain Drain).

\section{Author details}

${ }^{1}$ Centro de Estudos de Ciência Animal (CECA), Instituto de Ciências e Tecnologias Agrárias e Agro-Alimentares (ICETA), Universidade do Porto (UP), Portugal. ${ }^{2}$ Departamento de Clínicas Veterinárias, Instituto de Ciências Biomédicas Abel Salazar (ICBAS), Universidade do Porto (UP), Portugal. ${ }^{3}$ Faculdade de Motricidade Humana (FMH), Universidade Técnica de Lisboa (UTL), Portugal. ${ }^{4}$ Department of Clinical and Biological Sciences, University of Turin, Italy. ${ }^{5}$ Departamento de Ciências Veterinárias, Universidade de Trás-osMontes e Alto Douro (UTAD), Portugal.

\section{Authors' contributions}

SA, APV and ASPV carried out the kinematic collecting data and the kinematic data analysis, participated in the functional data analysis, JMR and ALL carried out the animal surgeries, euthanasia, preparation of samples for histological and stereological analysis and participated in the functional evaluation analysis, PASADS carried out all the statistical analysis, the interpretation of kinematic data and participated in the paper draft, MV, AGand MJS performed the functional evaluation and analysis and were responsible for keeping the experimental animals, MF, SR, and SG performed the histological and stereological analysis, ACM carried out the animal surgeries euthanasia and preparation of samples for histological and stereological analysis. ACM together with SG and PASADS designed and coordinated the study, elaborated the manuscript and were responsible for the funding acquisition. All the authors read and approved the final manuscript.

\section{Competing interests}

The authors declare that they have no competing interests.

Received: 4 September 2009

Accepted: 11 February 2010 Published: 11 February 2010

\section{References}

1. Lundborg G: Bridging nerve defects: the role of tissue interpositioning. Severe Traumatic Defects of the Upper Limb London: Martin DunitzMasquelet AC, Ferreira AC 2003, 153-167.

2. Matsuyama T, Mackay M, Midha R: Peripheral nerve repair and grafting techniques: a review. Neurol Med Chir 2000, 40:187-199.

3. Siemionow M, Brzezicki G: Current techniques and concepts in peripheral nerve repair. Int Rev Neurobiol 2009, 87:139-170.

4. Gordon T, Sulaiman OA, Ladak A: Electrical Stimulation for Improving Nerve Regeneration: Where do we stand?. Int Rev Neurobiol 2009, 87:433-444.

5. Doolabh VB, Hertl MC, Mackinnon SE: The Role of Conduits in Nerve Repair, a Review. Rev Neurosci 1996, 7:47-84.

6. Jensen JN, Tung TH, Mackinnon SE, Brenner MJ, Hunter DA: Use of antiCD40 ligand Monoclonal Antibody as Antirejection Therapy in a Murine Peripheral Nerve Allograft Model. Microsurgery 2004, 24:309-315.

7. Lundborg G: Alternatives to Autologous Nerve Grafts. Handchir, Mikrochir, Plast Chir 2004, 36:1-7.

8. Geuna S, Papalia I, Tos P: End-to-side (Terminolateral) Nerve Regeneration: a Challenge for Neuroscientists Coming from an Intriguing Nerve Repair Concept. Brain Res Rev 2006, 52:381-388.

9. Chen YS, Hsieh CL, Tsai CC, Chen TH, Cheng WC, Hu CL, Yao CH: Peripheral nerve regeneration using silicone rubber chambers filled with collagen, laminin and fibronectin. Biomaterials 2000, 21:1541-1547.

10. Den Dunnen WFA, Van Wessel R, Pennings AJ, Robinson PH, Van Leeuwen MBM, Schakenraad JM: Long-term evaluation of degradation and foreign body reaction of subcutaneously implanted poly (DLlactide-ع-caprolactone). J Biomed Mater Sci 1997, 36:337-346. 
11. Schmidt CE, Leach JB: Neural Tissue Engineering: Strategies for repair and regeneration. Annu Rev Biomed Eng 2003, 5:293-347.

12. Luís AL, Rodrigues JM, Geuna S, Amado S, Shirosaki Y, Lee JM, Fregnan F, Lopes MA, Veloso AP, Ferreira AJ, Santos JD, Armada-da-Silva PAS, Varejão ASP, Maurício AC: Use of PLGA 90:10 scafolds enriched with in vitro-differentiated neural cells for repairing rat sciatic nerve defects. Tissue Engineering Part A 2008, 14(6):979-993.

13. Luís AL, Rodrigues JM, Geuna S, Amado S, Simões MJ, Fregnan F, Ferreira AJ, Veloso AP, Armada-da-Silva PAS, Varejão ASP, Maurício AC: Neural cell transplantation effects on sciatic nerve regeneration after standardized crush injury in the rat. Microsurgery 2008, 28(6):458-470.

14. Amado S, Simões MJ, Armada-da-Silva PAS, Luís AL, Shirosaki Y, Lopes MA Santos JD, Fregnan F, Gambarotta G, Raimondo S, Fornaro M, Veloso AP, Varejão ASP, Maurício AC, Geuna S: Use of hybrid chitosan membranes and $\mathrm{N} 1 \mathrm{E}-115$ cells for promoting nerve regeneration in an axonotmesis rat model. Biomaterials 2008, 29(33):4409-4419.

15. Battiston B, Raimondo S, Tos P, Gaidano V, Audisio C, Scevola A, Perroteau I, Geuna S: Tissue engineering of peripheral nerves. Int Rev Neurobiol 2009, 87:225-250.

16. Karagoz H, Ulkur E, Uygur F, Senol MG, Yapar M, Turan P, Celikoz B: Comparison of regeneration results of prefabricated nerve graft, autogenous nerve graft, and vein graft in repair of nerve defects. Microsurgery 2009, 29:138-143.

17. Zacchigna S, Giacca M: Gene therapy perspectives for nerve repair. Int Rev Neurobiol 2009, 87:381-392.

18. Kauppila T, Jyvasjarvi E, Huopaniemi T, Hujanen E, Liesi P: A Laminin graft replaces neurorrhaphy in the restorative surgery of the rat sciatic nerve. Exp Neurol 1993, 123:181-191

19. Rutishauser U: Adhesion molecules of the nervous system. Curr Opin Neurobiol 1993, 3:709-715.

20. Tong XJ, Hirai K, Shimada H, Mizutani Y, Izumi T, Toda N, Yu P: Sciatic nerve regeneration navigated by laminin-fibronectin double coated biodegradable collagen grafts in rats. Brain Res 1994, 663:155-162.

21. Whitworth IH, Brown RA, Dore C, Green CJ, Terenghi G: Orientated mats of fibronectin as a conduit material for use in peripheral nerve repair. $J$ Hand Surg (Br) 1995, 20:429-36.

22. Ahmed Z, Brown RA: Adhesion, alignment, and migration of cultured Schwann cells on ultrathin fibronectin fibres. Cell Motil Cytoskelet 1999, 42:331-343.

23. Yoshii S, Oka M: Peripheral Nerve Regeneration along Collagen Filaments. Brain Res 2001, 888:158-162.

24. Grimpe B, Silver J: The extracellular matrix in axon regeneration. Prog Brain Res 2002, 137:333-349.

25. Toba T, Nakamura T, Lynn AK, Matsumoto K, Fukuda S, Yoshitami M, Hori Y, Shimizu Y: Evaluation of peripheral nerve regeneration across an $80-\mathrm{mm}$ gap using a polyglycolic acid (PGA)-collagen nerve conduit filled with laminin-soaked collagen sponge in dogs. Int J Artif Organs 2002, 25:230-237.

26. Itoh S, Takakuda K, Kawabata S, Aso Y, Kasai K: Evaluation of crosslinking procedures of collagen tubes used in peripheral nerve repair. Biomaterials 2002, 23:4475-4481.

27. Yoshii S, Oka M, Shima M, Taniguchi A, Akagi M: Regeneration of rat sciatic nerve along collagen filaments. Brain Res 2002, 949:202-208.

28. Ceballos D, Navarro X, Dubey N, Wendelschafer-Crabb G, Kennedy WR, Tranquillo RT: Magnetically aligned collagen gel filling a collagen nerve guide improves peripheral nerve regeneration. Exp Neurol 1999, 158:290-300.

29. Dubey N, Letourneau PC, Tranquillo RT: Guided Neurite Elongation and Schwann Cell Invasion Into Magnetically Aligned Collagen in Simulated Peripheral Nerve Regeneration. Exp Neurol 1999, 158:338-350.

30. Archibald SJ, Shefner J, Krarup C, Madison RD: Monkey median nerve repaired by nerve graft or collagen nerve guide tube. J Neurosci 1995, 15:4109-4123.

31. Chamberlain LJ, Yannas IV, Hsu HP, Strichartz G, Spector M: Collagen- GAG substrate enhances the quality of nerve regeneration through collagen tubes up to level of autograft. Exp Neurol 1998, 154:315-329.

32. Chamberlain LJ, Yannas IV, Hsu HP, Strichartz GR, Spector M: Near-terminus axonal structure and function following rat sciatic nerve regeneration through a collagen-GAG matrix in a ten millimeter gap. J Neurosci Res 2000, 60:666-677.
33. Fu SY, Gordon T: The cellular and molecular basis of peripheral nerve regeneration. Mol Neurobiol 1997, 14:67-116.

34. Tria MA, Fusco M, Vantini G, Mariot R: Pharmacokinetics of nerve growth factor (NGF) following different routes of administration to adult rats. Exp Neurol 1994, 127:178-183.

35. Amano TER, Niremberg M: Neurotransmitter synthesis by neuroblastoma clones (neuroblast differentiation-cell culture-choline acetyltransferaseacetylcholinesterase-tyrosine hydroxylase-axons-dendrites). Proc Natl Acad Sci (USA) 1972, 69:258-263.

36. Rodrigues JM, Luís AL, Lobato JV, Pinto MV, Faustino A, Sooraj Hussain N, Lopes MA, Veloso AP, Freitas M, Geuna S, Santos JD, Maurício AC: Intracellular $\mathrm{Ca}^{2+}$ concentration in the N1E-115 neuronal cell line and its use for peripheric nerve regeneration. Acta Med Portug 2005, 18:323-328.

37. Rodrigues JM, Luís AL, Lobato JV, Pinto MV, Lopes MA, Veloso AP, Freitas M, Geuna S, Santos JD, Maurício AC: Determination of the intracellular $\mathrm{Ca}^{2+}$ concentration in the N1E-115 neuronal cell line in perspective of its use for peripheric nerve regeneration. J Bio-Medical Mat Eng 2005, 15:455-465.

38. Kimhy Y, Spector I, Barak Y, Littauer UZ: Maturation of neuroblastoma cells in the presence of dimethylsulfoxide. Proc Natl Acad Sci (USA) 1976, 73:462-466.

39. De Laat SL, Saag van der PT: The plasma membrane as a regulatory site in growth and differentiation of neuroblastoma cells. Int Rev Cyt 1982, 74:1-7.

40. Reagan $L P$, Ye X, Mir R, DePalo R, Fluharty J: Up-regulation of angiotensin II receptors by in vitro differentiation of murine N1E-115 neuroblastoma cells. Mol Pharmacol 1990, 38:878-886

41. Larcher JC, Basseville M, Vaysierre JL, Cordeau-Lossouarn L, Croizat B, Gros F: Growth Inhibition of N1E-115 Mouse Neuroblastoma Cells by C-myc or $\mathrm{N}$-myc Antisense Oligodeoxynucleotides Causes Limited Differentiation but is not Coupled to Neurite Formation. Biochem. Biophys Res Comun 1992, 185:915-924.

42. Prasad KN: Differentiation of neuroblastoma cells: a useful model for neurobiology and cancer. Biol Rev Camb Philos Soc 1991, 66:431-451.

43. Prasad KN, Kentroti S, Edwards-Prasad J, Vernadakis A, Imam M, Carvalho E, Kumar S: Modification of the expression of adenosine 3', 5'-cyclic monophosphate-induced differentiated functions in neuroblastoma cells by beta-carotene and D-alpha-tocopheryl succinate. J Am Coll Nutr 1994, 13:298-303.

44. Kerns JM, Braverman B, Mathew A, Lucchinetti C, Ivankovich AD: A comparison of cryoprobe and crush lesions in the rat sciatic nerve. Pain 1991, 47:31-39.

45. Sporel-Ozakat ME, Edwards PM, Hepgul KT, Savas A, Gispen WH: A simple method for reducing autotomy in rats with peripheral nerve lesions. $J$ Neurosci Méthodes 1991, 36:263-265.

46. Thalhammer JG, Vladimirova M, Bershad-Sky B, Strichartz GR: Neurologic evaluation of the rat during sciatic nerve block with lidocaine. Anaesthesiology 1995, 82:1013-1025.

47. Koka R, Hadlock TA: Quantification of functional recovery following rat sciatic nerve transection. Exp Neurol 2001, 168:192-195.

48. Masters DB, Berge CB, Dutta SK, Griggs CT, Hu D, Kupsky W, Langer R: Prolonged regional nerve blockade by controlled release of local anesthetic from a biodegradable polymer matrix. Anesthesiology 1993, 79:340-346.

49. Hu D, Hu R, Berde CB: Neurologic evaluation of infant and adult rats before and after sciatic nerve blockade. Anaesthesiology 1997, 86:957-965.

50. Campbell JN: Nerve lesions and the generation of pain. Muscle Nerve 2001, 24:1261-1273.

51. Shir Y, Campbell JN, Raja SN, Seltzer Z: The Correlation between Dietary Soy Phytoestrogens and Neuropathic Pain Behavior in Rats after Partial Denervation. Anesth Analg 2002, 94(2):421-426.

52. Varejão ASP, Cabrita AM, Geuna S, Melo-Pinto P, Filipe VM, Gramsbergen A, Meek MF: Toe Out Angle: a functional index for the evaluation of sciatic nerve recovery in the rat model. Exp Neurol 2003, 183:695-699.

53. Varejão ASP, Cabrita AM, Meek MF, Bulas-Cruz J, Gabriel RC, Filipe VM, MeloPinto P, Winter DA: Motion of the foot and ankle during the stance phase in rats. Muscle Nerve 2002, 26:630-635.

54. Varejão ASP, Cabrita AM, Meek MF, Bulas-Cruz J, Filipe VM, Gabriel RC, Ferreira AJ, Geuna S, Winter D: Ankle kinematics to evaluate functional recovery in crushed rat sciatic nerve. Muscle Nerve 2003, 27:706-714.

55. Luís AL, Amado S, Geuna S, Rodriques JM, Simões MJ, Santos JD, Fregman F, Raimondo S, Veloso AP, Ferreira AJA, Armada-da-Silva PAS, 
Varejão ASP, Maurício AC: Long-term functional and morphological assessment of a standardized rat sciatic nerve crush injury with a nonserrated clamp. I Neurosci Methods 2007, 163:92-104.

56. Di Scipio F, Raimondo S, Tos P, Geuna S: A simple protocol for paraffinembedded myelin sheath staining with osmium tetroxide for light microscope observation. Microsc Res Tech 2008, 71:497-502.

57. Raimondo S, Fornaro M, Di Scipio F, Ronchi G, Giacobini-Robecchi MG, Geuna S: Methods and protocols in peripheral nerve regeneration experimental research: Part II - morphological techniques. Int Rev Neurobiol 2009, 87:79-101.

58. Geuna S, Tos P, Battiston B, Guglielmone R: Verification of the twodimensional disector, a method for the unbiased estimation of density and number of myelinated nerve fibers in peripheral nerves. Ann Anat 2000, 182:23-34.

59. Geuna S, Tos P, Guglielmone R, Battiston B, Giacobini-Robecchi MG: Methodological issues in size estimation of myelinated nerve fibers in peripheral nerves. Anat Embryol 2001, 204:1-10.

60. Geuna S, Gigo-Benato D, Rodrigues AC: On sampling and sampling errors in histomorphometry of peripheral nerve fibers. Microsurgery 2004, 24:72-76.

61. Geuna S: The revolution of counting "Tops": two decades of the disector principle in morphological research. Microsc Res Tech 2005, 66:270-274.

62. Seckel BR: Enhancement of peripheral nerve regeneration. Muscle Nerve 1990, 13:785-800.

63. Ide C: Peripheral nerve regeneration. Neurosci Res 1996, 25:101-121.

64. Terenghi $G$, Wiberg M, Kingham PJ: Use of stem cells for improving nerve regeneration. Int Rev Neurobiol 2009, 87:393-403.

65. Lundborg G: Enhancing posttraumatic nerve regeneration. J Periph Nerv Syst 2002, 7:139-140.

66. Chalfoun $C T$, Wirth GA, Evans GRJ: Tissue engineered nerve constructs: where do we stand?. J Cell Mol Med 2006, 10:309-317.

67. Tohill M, Terenghi G: Stem-cell plasticity and therapy for injuries of the peripheral nervous system. Biotechnol Appl Biochem 2004, 40:17-24.

68. Pfister LA, Papaloïzos M, Merkle HP, Gander B: Nerve conduits and growth factor delivery in peripheral nerve repair. J Peripher Nerv Syst 2007, 12:65-82.

69. Sinis N, Schaller HE, Becker ST, Schlosshauer B, Doser M, Roesner H, Oberhoffner S, Müller HW, Haerle M: Long nerve gaps limit the regenerative potential of bioartificial nerve conduits filled with Schwann cells. Restor Neurol Neurosci 2007, 25:131-141.

70. Dahlin L, Johansson F, Lindwall C, Kanje M: Future perspective in peripheral nerve reconstruction. Int Rev Neurobiol 2009, 87:507-530.

71. Chen MB, Zhang F, Lineaweaver WC: Luminal fillers in nerve conduits for peripheral nerve repair. Ann Plast Surg 2006, 57:462-471.

72. Li L, Mignone J, Yang M, Matic M, Penman S, Enikolopov G, Hoffman RM: Nestin expression in hair follicle sheath progenitor cells. Proceedings of the National Academy of Sciences USA 2003, 100:9958-9961.

73. Amoh Y, Li L, Katsuoka K, Penman S, Hoffman RM: Multipotent nestinpositive, keratin-negative hair-follicle bulge stem cells can form neurons. Proceedings of the National Academy of Sciences USA 2005, 102:5530-5534.

74. Amoh Y, Li L, Campillo R, Kawahara K, Katsuoka K, Penman S, Hoffman RM: Implanted hair follicle stem cells form Schwann cells that support repair of severed peripheral nerves. Proceedings of the National Academy of Sciences USA 2005, 102:17734-17738.

75. Amoh Y, Kanoh M, Niiyama S, Hamada Y, Kawahara K, Sato Y, Hoffman RM, Katsuoka K: Human hair follicle pluripotent stem (hfPS) cells promote regeneration of peripheral-nerve injury: an advantageous alternative to ES and iPS cells. Journal of Cellular Biochemistry 2009, 107:1016-1020.

doi:10.1186/1743-0003-7-7

Cite this article as: Amado et al: Effects of collagen membranes enriched with in vitro-differentiated N1E-115 cells on rat sciatic nerve regeneration after end-to-end repair. Journal of NeuroEngineering and Rehabilitation 2010 7:7.

\section{Submit your next manuscript to BioMed Central and take full advantage of:}

- Convenient online submission

- Thorough peer review

- No space constraints or color figure charges

- Immediate publication on acceptance

- Inclusion in PubMed, CAS, Scopus and Google Scholar

- Research which is freely available for redistribution

Submit your manuscript at www.biomedcentral.com/submit 